


\section{About IJMA [last updated October, $\left.1^{\text {st }}, 2021\right]$}

$\checkmark$ International Journal of Medical Arts is the Official Journal of the Damietta Faculty of Medicine, AlAzhar University, Egypt

$\checkmark$ It is an International, Open Access, Double-blind, Peer-reviewed Journal

$\checkmark$ Published four times a year

$\checkmark$ The First Issue was published in July 2019

$\checkmark$ Published under the following license: Creative Commons Attribution-ShareAlike 4.0 International Public License (CC BY-SA 4.0). It had updated from the Creative Commons license [CC BY] in volume 2, Issue 4, October 2020 About IJMA

$\checkmark$ The Egyptian Knowledge Bank hosts the web site of IJMA

$\checkmark$ The Egyptian Knowledge Bank supports IJMA

$\checkmark$ IJMA follows the regulations of the International Committee of Medical Journal Editors

$\checkmark$ IJMA is indexed in the "Directory of Open Access Journals" [15 January 2021].

$\checkmark$ IJMA is indexed in J-Gate [29-6-2021]

$\checkmark$ IJMA is a member of the International Society of Managing and Technical Editors

$\checkmark$ Listed in "Index Copernicus", "Publons", "Academic resource index [ResearchBib]" "Electronics journal library", "Eurasian Scientific Journal Index", "WorldCat" Superstar Journal Database, and "Citefactor"

$\checkmark$ IJMA introduced to the search engine [BASE] through DOAJ

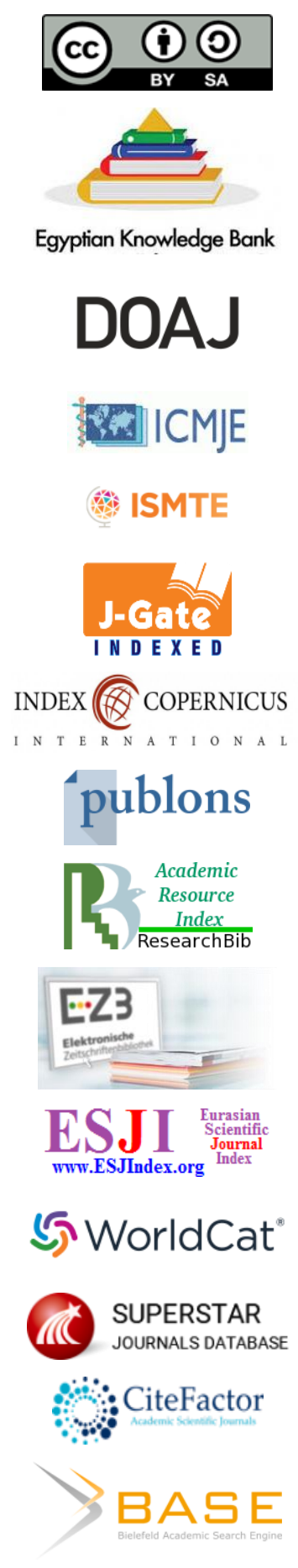




Available online at Journal Website
https://ijma.journals.ekb.eg/
Main subject [Respiratory Medicine] ${ }^{*}$

Original Article

\title{
Impact of Hepatitis C Virus Co-Infection on Tuberculous Patients
}

\author{
Eman Shawky Nageeb [1], Samiha Mohammed Abu-Bakr [2], Hoda Asaad Eid [2], Hanaa A. Abou-Elhassan [3]
}

1 Department of Chest Disease, Mansoura Chest Hospital, Egypt

2 Department of Chest Disease, Faculty of Medicine [for girls], Al-Azhar University, Egypt

${ }^{3}$ Department of Community Medicine, Faculty of Medicine [for girls], Al-Azhar University, Egypt

Corresponding author: Hanaa A. Abou-Elhassan

Email: hanaaabouelyazid@azhar.edu.eg

Submission date: September 18, 2021; Acceptance date: October 30, 2021

DOI: $10.21608 / / J M A .2021 .96766 .1366$

DOAJ

\section{ABSTRACT}

Background: Tuberculosis [TB] and hepatitis $\mathrm{C}$ virus [HCV] infections are both common infectious diseases. Although HCV infection is frequent in patients with TB, few studies have been conducted worldwide and there is still little evidence concerning this topic.

Aim of the work: To assess the prevalence of HCV infection among tuberculous patients and to investigate its impact on tuberculosis and its treatment outcome.

Patients and Methods: A cross-sectional study was done on 500 tuberculous patients. Socio-demographic data, clinical history and examination, clinical severity, response to drugs, laboratory and radiological investigation, Tuberculin skin test, and HCV screening were done.

Results: HCV infection was detected among 54 tuberculosis patients [10.8\%]. HCV-positive patients suffered more from almost all clinical presentation than HCV- negative patients but without statistical significant difference. Tuberculin skin test induration and reactions were more in HCV- negative patients with $17.9 \pm 4.9 \mathrm{~mm}$ compared to $12.9 \pm 2 \mathrm{~mm}$ in HCV- positive patients. Lung cavitation and lung infiltration were the most predominant radiological finding among HCV- positive patients. CAT [category] IV and modified CAT I were the most treatment regimen used in HCV-positive patients. Failure of treatment was significantly higher among HCV-positive patients [59.3\%] compared to $9.9 \%$ of their counterparts. Moreover, multidrug resistance [MDR] and rifampicin resistance were significantly higher in HCVpositive group than their comparable group [31.5\% and $29.6 \%$, and $9 \%$ and $4.3 \%$ respectively].

Conclusion: Co-infection of HCV in Patients with TB is frequent. It increases the frequency of almost all clinical presentation and had its predominant findings on laboratory and radiological investigations. Co-infection also alters the response to TB treatment and should be screened among tuberculous patients before treatment and closely monitored during treatment to detect early any drug resistance or treatment failure.

Keywords: Tuberculosis; Hepatitis c; Multidrug Resistant; Treatment Failure

This is an open-access article registered under the Creative Commons, ShareAlike 4.0 International license [CC BY-SA 4.0] [https://creativecommons.org/licenses/by-sa/4.0/legalcode. 1890 [DOI: 10.21608/IJMA.2021.96766.1366.

${ }^{*}$ Main subject and any subcategories have been classified according to the research topic 
INTRODUCTION

Both tuberculosis [TB] and hepatitis $\mathrm{C}$ virus [HCV] are threatening infectious diseases and they constitute major health problems, especially in endemic countries. The occurrence of $\mathrm{TB} /$ hepatitis co-infection is a considerable clinical and public-health challenge, as it may cause serious health hazards and put a significant burden on the community [1]. Generally, the prevalence of HCV infection in patients with TB has not been extensively studied. Only a limited amount of data on the rates of TB/HCV co-infection exists [2].

HCV has impact on the immune system, as the HCVpositive patients' present relative decline in naïve $T$ cells accompanied by impaired lymphocyte proliferative responses, which is essential in the defense against TB. The deteriorated cellular immune response on account of HCV infection would facilitate the development of intracellular infection [3]. The effect of HCV on TB-specific CD4+ T cells may be a mechanism for accelerated TB disease progression in TB/HCV-co-infected patients. This is because functionally impaired $\mathrm{CD} 4+\mathrm{T}$ cells may be unable to control TB replication, especially when this is accompanied with an increased level of IL-10 in the serum [4]. Dendritic cells generated in vitro from peripheral blood of individuals with HCV infection appear impaired in their capacity for antigen presentation, which correlates with decrease and dysfunction of dendritic cells. Moreover, HCV core protein could bind to and inhibit the receptor of tumor necrosis factor-alpha [TNF-a]. As TNF-a is essential cytokines for acute TB control [5]

Chronic liver disease raises the risk of hepatotoxicity during anti-tuberculosis treatment, up to three to five times more than tuberculous patients without a viral infection. This leads to increased complexity in the treatment of this group of TB/HCV patients [6].

\section{AIM OF THE WORK}

Although HCV is globally prevalent, the frequency of coinfection with TB, and the potential impact of this co-infection on the course and treatment outcome of TB disease have received little attention. Thus, the current study was conducted to assess the prevalence of HCV infection among tuberculous patients and to investigate its impact on tuberculosis and its treatment outcome.

\section{PATIENTS AND METHODS}

The current study is a cross-sectional that was conducted on 500 tuberculous patients who were randomly chosen from the attendees of four Chest hospitals [Mansoura Chest Hospital, Abassia chest hospital, Mahalla
Chest Hospital, and Damietta chest hospital] during the period from October 2017 to December 2019.

Sample size: Sample size $[\mathrm{N}]$ was calculated from the following formula:

$$
N=Z a / 2^{2 *} p^{*}[1-p] / \operatorname{MOE} 2[7] .
$$

Where $Z a / 2$ is the critical value of the normal distribution at $a / 2$ [for a confidence level of $95 \%, a$ is 0.05 and the critical value is 1.96], MOE is the margin of error $=4 \%, p$ is the prevalence of $\mathrm{HCV}$ among tuberculosis patients considering previous study [17\%] [8]. Consequently, $N=$ $[1.96]^{2}{ }^{*} 0.17^{\star} 0.83 /[0.04] 2=339$. So, our sample size is 339 eligible patients with TB who were increased to 500 during the field work to compensate for the probable dropout.

Inclusion criteria: Patients with Mycobacterium tuberculosis infection [pulmonary and extra pulmonary tuberculosis], aged 14 years and above from both sexes.

Exclusion criteria: Tuberculous patients have any malignancies or with history of chemotherapy or radiotherapy exposure.

Ethical considerations: The study objectives and tools were explained to the participants. This study was conducted after approval by the institutional review board [IRB], faculty of medicine for girls Al-Azhar University, Cairo, Egypt. Participation was voluntary; informed consent was obtained from each study participant before enrollment in the study. Withdrawal from the study was assured for all participants without giving any reasons and without affecting their rights of medical care. Also, data were anonymous and coded to assure confidentiality of participants.

\section{Tools and data collection}

- Socio-demographic data with special emphasis on age/years, sex, residence, and occupation,

- Clinical history and proper examination were carried out.

- Complete blood count, kidney and liver function tests, erythrocyte sedimentation rate were done using HITACH9-911 TM autoanalyzer.

- All patients underwent a standard single view plain X-ray chest with postero-anterior view to detect any findings suggestive of pulmonary tuberculosis. CT chest was done for the most indicated and suspicious cases.

- Tuberculin skin test: intradermal injection of $0.1 \mathrm{~mL}$ of a liquid containing 5 TU of PPD. Proper injection was evaluated by the appearance of a pale and discrete elevation of the skin $[6 \mathrm{~mm}-10 \mathrm{~mm}]$ in diameter. Skin test was interpreted based on the presence or absence and 
the amount of induration [localized swelling] after $72 \mathrm{~h}$.

- Sputum smear microscopy was done for all patients. Patients were asked to collect the first sample at the time of the consultation when the patient was identified as a suspected TB case. The second sample was collected in the early morning the day after the initial consultation. The samples were stained by Ziehl-Neelsen stain.

- Sputum or body fluid samples were collected from the patient with suspected TB and Gene Xpert was done using [Cepheid gene Xpert MTBIRIF assay device Sunnyvale, California].

- In all patients, HCV antibody rapid test was done, $3 \mathrm{ml}$ of venous blood samples was drawn were 5 ul of serum was transferred by pipette to the specimen well of the test device then 2 full drops of buffer were added then positive or negative or invalid results were interpreted.

- HCV RNA PCR test was done using [step One Real time PCR System] to confirm a diagnosis of hepatitis $c$ virus infection. A viral load over $800,000 \mathrm{IU} / \mathrm{ml}$ was considered high. A low viral load would be less than $800,000 \mathrm{IU} / \mathrm{ml}$.

Statistical analysis: Analysis of data was carried out with SPSS version 21. Testing the normality of data was done with one-sample Kolmogorov-Smirnov test. Number and percentage were used to describe qualitative data. Association between categorical variables was tested using chi-square test. Continuous variables were described as mean \pm SD [standard deviation] for parametric data and median for non-parametric data. The two groups were compared with student t- test when data were parametric while non- parametric data were compared by MannWhitney U test.

\section{RESULTS}

The prevalence of HCV infections among the studied tuberculous patients was 10.8\% [Table 1].

Mean age was significantly higher among HCV- positive than HCV-negative tuberculous patients [ $49 \pm 12.4$ and 40.4 \pm 12.7 respectively $\mathrm{P}=0.000$ ]. Regarding gender $96.3 \%$ of the HCV- positive were male comparing to $81.4 \%$ of negative HCV patients $[p<0.05]$.Concerning occupation, marital status, and residence there were no statistically significant differences between HCV- positive and negative groups [Table 2].
$\mathrm{HCV}$ - positive patients suffered in more frequencies from all clinical presentation than HCV- negative patients without statistical significant difference except for chest pain [p $<0.05$ ] [Figure 1].

Great affection was detected regarding platelet count and liver function tests [including serum albumin, serum bilirubin, ALT and AST] in HCV- positive patients compared with HCVnegative patients with high significant differences [ $p<0.001]$. Positive smear results were noticed more in HCV- positive tuberculous patients [92.5\%] compared to their comparable group [78.69\%] with a statistically significant difference. Tuberculin skin test was positive among $42.6 \%$ of HCVpositive patients compared to $70 \%$ of $\mathrm{HCV}$ - negative patients with a statistically significant difference $[p<0.001]$. Tuberculin skin test induration and reaction was significantly lower [12.9 $\pm 2 \mathrm{~mm}]$ in HCV-positive patients than their counterparts [17.9 $\pm 4.9 \mathrm{~mm}$ ] [Table 3].

Radiological findings in general were noticed more in $\mathrm{HCV}$ - positive tuberculous patients. Both lung cavitation and lung infiltration were more frequent among HCV- positive tuberculous patients compared to HCV- negative ones. Lung masses or nodules and paravertebral abscess were much less common in HCV-positive compared to HCV- negative patients. Lung destruction and pleural effusion were more prevalent among HCV- positive patients compared to HCVnegative patients. All these differences were statistically insignificant [Table 4]

Regarding clinical profile of TB in the patients being studied, it was found that most of HCV- positive and negative patients were presented by pulmonary tuberculosis $[77.7 \%$ and $84.7 \%$ respectively $p$ value $>0.05]$. Concerning treatment, failure of treatment was higher among HCVpositive patients [59.3\%] compared to $9.9 \%$ of HCVnegative ones with a high statistically significant difference [ $p<0.001$ ]. In addition, CAT IV and modified CAT I were the most treatment regimen used in HCV- positive patients [61.1\% and $38.9 \%$ ] respectively compared to $10.7 \%$ and $0.4 \%$ in HCV- negative patients with a high statistically significant difference $[p<0.001]$. High incidence of drug resistance by GENEXERT was detected in HCV- positive patients as about one- third of them [31.5\%] showed multidrug resistance [MDR] and $29.6 \%$ of them were rifampicin resistance compared to $9 \%$ and $4.3 \%$ respectively in HCV- negative patients with a high statistically significant difference $[p<0.001]$ [Table 5].

Table [1]: Prevalence of HCV among Tuberculous patients

\begin{tabular}{|c|c|}
\hline & Tuberculous patients [n=500] \\
\hline HCV results & No. [500] \\
\hline Positive & $54[10.8 \%]$ \\
\hline Negative & $446[89.2 \%]$ \\
\hline
\end{tabular}


Table [2]: Comparing between both groups regarding laboratory data

\begin{tabular}{|c|c|c|c|c|c|}
\hline & & HCV- positive Patients [n=54] & HCV-negative Patients [n=446] & Test & Pvalue \\
\hline Age in & $\leq 20$ & $1[1.9 \%]$ & $20[4.48 \%]$ & \multirow{4}{*}{29.1} & \multirow{4}{*}{$0.000^{* *}$} \\
\hline \multirow[t]{4}{*}{ years: } & $21-40$ & $11[20.4 \%]$ & 216 [48.4\%] & & \\
\hline & $4-60$ & $31[57.4 \%]$ & $188[42.1 \%]$ & & \\
\hline & $61-75$ & $11[20.4 \%]$ & $22[4.9 \%]$ & & \\
\hline & Mean \pm SD & $49 \pm 12.4$ & $40.4 \pm 12.7$ & 7437 & $0.00^{* *}$ \\
\hline \multirow[t]{2}{*}{ Gender } & Male & 52 [96.3\%] & 363 [81.4\%] & \multirow{2}{*}{7.5} & \multirow{2}{*}{$0.004^{*}$} \\
\hline & Female & $2[3.7 \%]$ & $83[18.6 \%]$ & & \\
\hline \multirow{4}{*}{$\begin{array}{l}\text { Marital } \\
\text { status }\end{array}$} & Single & $3[5.6 \%]$ & $105[23.5 \%]$ & \multirow{4}{*}{11.15} & \multirow{4}{*}{$0.006^{*}$} \\
\hline & Married & $49[90.7 \%]$ & $313[70.2 \%]$ & & \\
\hline & Divorced & $0[0 \%]$ & $9[2 \%]$ & & \\
\hline & Widowed & $2[3.7 \%]$ & $19[4.3 \%]$ & & \\
\hline \multirow[t]{4}{*}{ Residence } & Upper Egypt & $8[14.8 \%]$ & 68 [15.2\%] & \multirow{4}{*}{0.46} & \multirow{4}{*}{0.794} \\
\hline & Delta & $37[68.5 \%]$ & $307[68.8 \%]$ & & \\
\hline & Cairo & $8[14.8 \%]$ & $55[12.3 \%]$ & & \\
\hline & Frontiers & $1[1.9 \%]$ & $16[3.6 \%]$ & & \\
\hline \multirow[t]{2}{*}{ Occupation } & Workers & $33[61.1 \%]$ & $307[68.8 \%]$ & \multirow{2}{*}{1.32} & \multirow{2}{*}{0.28} \\
\hline & Non-workers & $21[38.9 \%]$ & $139[31.2 \%]$ & & \\
\hline
\end{tabular}

${ }^{*}$ significant difference [p value $\left.<0.05\right]$.

Figure (1): Clinical presentations among the Studied Patients

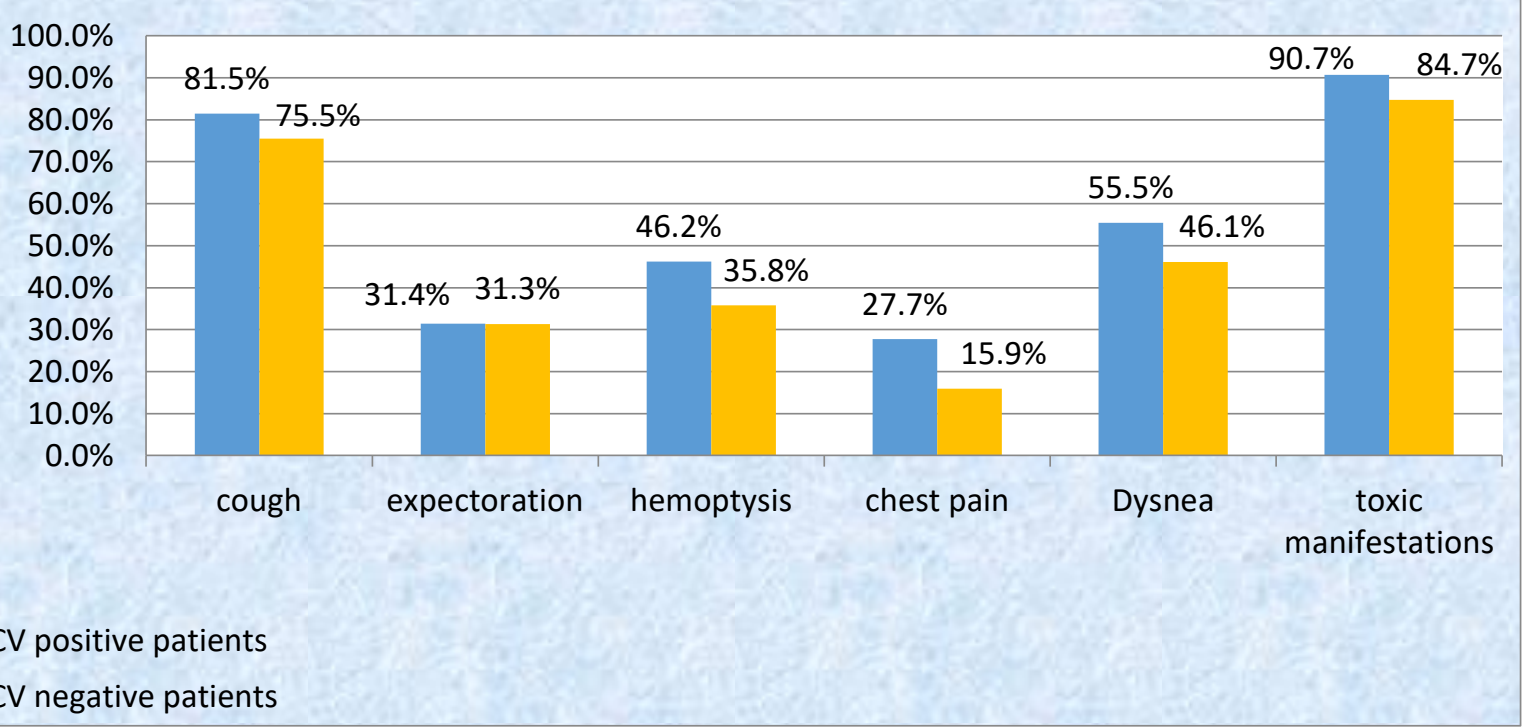

Table [3]: Laboratory findings among the studied patients

\begin{tabular}{|c|c|c|c|c|}
\hline & HCV- positive Patients [n=54] & HCV-negative Patients [n=446] & Test & P value \\
\hline HB & $11.9 \pm 1.7$ & $11.6 \pm 1.7$ & 11166 & 0.382 \\
\hline WBCs & $8.9 \pm 3.4$ & $9.4 \pm 4.0$ & 11329.5 & 0.477 \\
\hline PLT & $252 \pm 111.0$ & $335 \pm 122.0$ & 7012 & $.000^{\star *}$ \\
\hline ESR & $67 \pm 29.0$ & $69.18 \pm 29.0$ & 11327.5 & 0.476 \\
\hline Albumin & $3.33 \pm 0.4$ & $4.06 \pm .49 .0$ & 2696 & $.000^{* *}$ \\
\hline Bilirubin & $1.5 \pm 0.56$ & $.87 \pm .19 .0$ & 1933.5 & $0.000^{* *}$ \\
\hline ALT & $49.9 \pm 27.4$ & $21 \pm 11.1$ & 3009 & $0.000^{* \star}$ \\
\hline AST & $52.9 \pm 31$ & $22.6 \pm 13$ & 2803 & $0.000^{* \star}$ \\
\hline S. creatinine & $.87 \pm .18$ & $0.83 \pm 0.18$ & 10776 & 0.2 \\
\hline Positive Smear result & 50 [92.5\%] & 351 [78.69\%] & 5.85 & $.017^{*}$ \\
\hline $\begin{array}{lc}\text { Tuberculin } & \text { Positive335 } \\
\text { skin test } & \text { Negative165 }\end{array}$ & $\begin{array}{l}23[42.6 \%] \\
31[57.4 \%]\end{array}$ & $\begin{array}{l}312[70 \%] \\
134[30 \%]\end{array}$ & 16.3 & $0.000^{*}$ \\
\hline Tuberculin Skin Test mean \pm SD & $12.9 \pm 2.0$ & $17.9 \pm 4.9$ & 1178.5 & $0.000^{*}$ \\
\hline
\end{tabular}

*significant difference [p value $<0.05$ ]. 
Table [4]: Radiological findings among the studied patients

\begin{tabular}{|c|c|c|c|c|c|}
\hline & & HCV- positive Patients [n=54] & HCV- negative Patients [ $n=446]$ & Test & $P$ value \\
\hline \multirow[t]{3}{*}{ Radiology } & Normal & $0[0 \%]$ & $10[2.24 \%]$ & 1.23 & 0.61 \\
\hline & No & $17[31.4 \%]$ & $155[34.75 \%]$ & & \\
\hline & The right lung & 14 [25.9\%] & 73 [16.36\%] & & \\
\hline \multirow[t]{2}{*}{ Cavitary lesion } & The left lung & $1[1.85]$ & $33[7.39 \%]$ & 4.86 & 0.23 \\
\hline & Bilateral & $22[40.7 \%]$ & $185[41.47 \%]$ & & \\
\hline \multirow[t]{4}{*}{ Lung infiltrate } & No & $17[31.4 \%]$ & $155[34.75 \%]$ & & \\
\hline & The right lung & 14 [25.9\%] & $75[16.8 \%]$ & & \\
\hline & The left lung & $1[1.85]$ & $33[7.39 \%]$ & $4.5 /$ & 0.22 \\
\hline & Bilateral & $22[40.7 \%]$ & $183[41.03 \%]$ & & \\
\hline \multicolumn{2}{|l|}{ Paravertebral abscess } & $0[0 \%]$ & $4[0.89 \%]$ & 0.488 & 0.485 \\
\hline \multicolumn{2}{|l|}{ Lung mass } & $0[0 \%]$ & $6[1.34 \%]$ & 0.735 & 0.391 \\
\hline \multirow[t]{3}{*}{ Destroyed lung } & No & 48 [88.88\%] & $403[90.35 \%]$ & & \\
\hline & The right lung & $4[7.4 \%]$ & 34 [7.62\%] & 0.637 & 0.611 \\
\hline & The left lung & $2[3.7]$ & $9[2.01 \%]$ & & \\
\hline \multirow[t]{3}{*}{ Pleural effusion } & The right lung & $4[7.4]$ & 29 [6.5\%] & & \\
\hline & The left lung & $2[3.7 \%]$ & 13 [2.91\%] & 0.41 & 0.834 \\
\hline & Bilateral & $0[0 \%]$ & $2[0.44 \%]$ & & \\
\hline
\end{tabular}

Table [5]: Tuberculosis profile and treatment outcome among the studied patients

\begin{tabular}{|c|c|c|c|c|c|}
\hline & & $\begin{array}{c}\text { HCV-positive Patients } \\
{[n=54]}\end{array}$ & $\begin{array}{l}\text { HCV- negative } \\
\text { Patients [ } n=446]\end{array}$ & Chi square & P value \\
\hline The type of TB & $\begin{array}{c}\text { pulmonary } \\
\text { Extra pulmonary } \\
\text { Pulmonary and extra pulmonary }\end{array}$ & $\begin{array}{c}42[77.7 \%] \\
10[18.5 \%] \\
2[3.7 \%]\end{array}$ & $\begin{array}{c}378[84.7 \%] \\
59[13.2 \%] \\
9[2 \%]\end{array}$ & 1.87 & 0.391 \\
\hline TB category & $\begin{array}{l}\text { New } \\
\text { Relapse } \\
\text { Defaulter } \\
\text { Failure }\end{array}$ & $\begin{array}{c}19[35.2 \%] \\
2[3.7 \%] \\
1[1.9 \%] \\
32[59.3 \%]\end{array}$ & $\begin{array}{c}308[69.1 \%] \\
60[13.5 \%] \\
34[7.6 \%] \\
44[9.9 \%]\end{array}$ & 91.1 & $0.000^{*}$ \\
\hline $\begin{array}{l}\text { TB } \\
\text { Treatment }\end{array}$ & $\begin{array}{c}\text { CAT I } \\
\text { Modified CAT I } \\
\text { Cat II } \\
\text { Cat IV }\end{array}$ & $\begin{array}{c}0[0.0 \%] \\
21[38.9 \%] \\
0[0.0 \%] \\
33[61.1 \%]\end{array}$ & $\begin{array}{c}298[66.8 \%] \\
2[0.4 \%] \\
91[20.4 \%] \\
55[10.7 \%]\end{array}$ & 250.0 & $0.000^{*}$ \\
\hline $\begin{array}{l}\text { Drug } \\
\text { resistance }\end{array}$ & $\begin{array}{c}\text { Non- resistant } \\
\text { Rifampicin resistance Multidrug } \\
\text { resistant }\end{array}$ & $\begin{array}{l}21[38.9 \%] \\
16[29.6 \%] \\
17[31.5 \%]\end{array}$ & $\begin{array}{c}387[86.8 \%] \\
19[4.3 \%] \\
40[9 \%]\end{array}$ & 79.2 & $0.000^{*}$ \\
\hline
\end{tabular}

*: significant difference [p value $<0.05]$.

\section{DISCUSSION}

Tuberculosis and HCV are still among the most lifethreatening infectious agents. They have a high mortality rate in adults especially in developing countries where these two diseases have similar epidemiological risk factors [9]. However, the causal link between HCV infection and TB risk is still unclear. Prevention, care, and treatment of TB and HCV can be successful, and both diseases can be cured. Inadequate disease screening, limited and insensitive diagnosis, difficult treatment regimens with varying toxicities, and complicated pharmaco-kinetic and pharmaco-dynamic drug interactions; these could result in delayed diagnosis, acknowledged treatment initiation, and low rates of completion, with the possibility for generation and spread of drug resistant organisms ${ }^{[10] .}$
Thus, the current study was done to assess the prevalence of $\mathrm{HCV}$ infection among tuberculous patients and to investigate its impact on tuberculosis and its treatment outcome. The prevalence of HCV among patients with TB varies internationally. HCV prevalence was reported by Reis et al. ${ }^{[11]}$ to be $7.5 \%$ while in Thailand, a study revealed a very high prevalence of HCV [31\%] [12]. Another study carried out in Georgia, Richards et al. [13] found that $22 \%$ were HCV seropositive, and Kuniholm et al. ${ }^{[14]}$ revealed $12 \%$ HCVpositives, while Wang et al. ${ }^{[7]}$ showed HCV 6.7\%, Khalil et al. [15] documented HCV co-infections in TB were 28 [27.45\%]. We studied five Hundred patients with tuberculosis either pulmonary or extra pulmonary, and found that $10.6 \%$ of them were positive for HCV, most of HCV- positive and negative patients were presented by pulmonary tuberculosis [ $77.7 \%$ and $84.7 \%$ respectively]. 
HCV-positive patients were found to be more prevalent among the age group 41-60 years with male predominance. Supporting to the current study, Merza et al. [16] found male predominance with 127 [59.3\%] males and 87 [40.7\%] females. The mean age of the patients was 40.34 years \pm 20.29 . In the same line, Behzadifar et al. [17] showed that men had a higher risk of HCV than women. In disagreement with the current study, Kuniholm et al. ${ }^{[14]}$ showed that HCV seropositivity in patients with TB did not differ significantly by gender.

Concerning laboratory findings among tuberculosis patients, there was a statistically significant difference among HCV-positive and HCV-negative tuberculous cases in terms of PLT, albumin, bilirubin, ALT, AST $[p<0.001]$ for each of them and positive smear result $[p=0.017]$. An important note must be considered, significant variations in blood parameters of pulmonary TB and TB-associated coinfected patients [such as HCV] suggest the investigation of associated abnormalities in patients with TB to rule out the co-infection before the start of TB treatment therapy. Similarly, Javed et al. ${ }^{[18]}$ stated that there were statistically significant differences among control, cases with TB only and Co-infection TB/HCV cases in terms of RBCs, HB, WBCs, platelet, neutrophil, monocytes, and ESR $[P<0.001]$.

In the current study the Tuberculin skin test was done for all patients, it was positive in $42.6 \%$ of HCV- positive patients compared to $70 \%$ in HCV- negative patients with statistical significance $[p<0.001]$, and there was a significant smaller tuberculin skin test induration in HCV positive patients with induration $12.9 \pm 2 \mathrm{~mm}$ compared to $17.9 \pm 4.9$ in HCV-negative patients $[p<0.001]$. Compared to Some authors reported the induration mean of the tuberculin skin test to be $14.7 \pm 6.9 \mathrm{~mm}$ in patients with a viral etiology and $6.1 \pm 5.4 \mathrm{~mm}$ in those with a non-viral etiology $[p<0.05]$. Another two studies found insignificant difference between the two groups regarding the tuberculin test $[19,20]$.

Another important finding of the current study is failure of treatment which was higher among HCV- positive tuberculous patients [59.3\%] compared with HCV- negative patients $[9.9 \%$ ] with a high statistically significant difference $[p<0.001]$. Tuberculous patients with multidrug-resistant coinfected with HCV are more likely to develop drug-induced liver injury [3], one of the most common adverse events during treatment of MDR-TB with reported rates at $9.7 \%$ $22.3 \%$. Hence, the treatment of HCV co-infection patients with MDR-TB could be beneficial ${ }^{211}$. Our study showed a high incidence of drug resistance by GENEXERT in HCVpositive patients as about one- third of them showed multidrug resistance [MDR] and $29.6 \%$ were rifampicin resistant compared to $9 \%$ and $4.3 \%$ respectively, in HCVnegative tuberculous patients with a statistically significant value [p<0.001]. Seung et al. ${ }^{[22]}$ supported this finding as they revealed high prevalence of hepatitis $\mathrm{C}$ infection among multidrug resistant tuberculous patients.

As regards radiological findings in tuberculous patients, our study illustrated that radiological affection was noticed more frequently in HCV- positive patients. Both lung cavitation and lung infiltration were more frequent among $\mathrm{HCV}$ - positive compared to HCV- negative tuberculous patients without a statistically significant difference [p=0.2], Also there were no statistical significant differences among $\mathrm{HCV}$ - positive and HCV- negative tuberculosis cases in paravertebral abscess $[\mathrm{p}=0.485]$, lung mass $[\mathrm{p}=0.391]]$, destroyed lung $[p=0.611]$ and Pleural effusion $[p=0.834]$

In the same line with our study, Darwish et al. [23] studied the effect of HCV infection on patients with pulmonary tuberculosis. They found that diffuse infiltration and cavitary lesion were the predominant findings in $\mathrm{HCV}$ patients.

\section{CONCLUSION}

Co-infection of HCV in Patients with TB is frequent. It increases the frequency of almost all clinical presentation and had its predominant findings on laboratory and radiological investigations. Co-infection also alters the response to TB treatment and should be screened among tuberculous patients before treatment and closely monitored during treatment to detect early any drug resistance or treatment failure.

Financial and Non-financial Relationships and Activities of Interest

None

\section{REFERENCES}

1. Kandeel A, Genedy M, El-Refai S, Funk AL, Fontanet A, Talaat M. The prevalence of hepatitis $C$ virus infection in Egypt 2015: implications for future policy on prevention and treatment. Liver Int. 2017 Jan; 37[1]:45-53. DOI: 10.1111/liv.13186.

2. Agha MA, El-Mahalawy II, Seleem HM, Helwa MA. Prevalence of hepatitis $C$ virus in patients with tuberculosis and its impact in the incidence of anti-tuberculosis drugs induced hepatotoxicity. Egypt J Chest Dis Tuberc. 2015 Jan 1;64[1]:91-6. DOI: 10.1016/j.ejcdt.2014.09.009.

3. Ali ME, El-Badawy O, Afifi NA, Eldin AS, Hassan EA, Halby HM, El-Mokhtar MA. Role of T-Helper 9 Cells in Chronic Hepatitis C-Infected Patients. Viruses. 2018 Jun 24;10[7]:341. DOl: 10.3390/v10070341.

4. El-Mokhtar MA, Elgendy SG, Eldin AS, Hassan EA, Hasan AAA, Abdel Hameed MR, Sayed D, Salama EH. Hepatitis C Virus Affects Tuberculosis-Specific T Cells in HIV-Negative Patients. 
Viruses. 2020 Jan 15;12[1]:101. DOI: 10.3390/v12010101.

5. Kaufmann SH. Protection against tuberculosis: cytokines, $\mathrm{T}$ cells, and macrophages. Ann Rheum Dis. 2002 Nov;61 Suppl 2[Suppl 2]:ii54-8. DOI: 10.1136/ard.61.suppl_2.ii54.

6. Chien JY, Huang RM, Wang JY, Ruan SY, Chien YJ, Yu CJ, Yang PC. Hepatitis $C$ virus infection increases hepatitis risk during anti-tuberculosis treatment. Int J Tuberc Lung Dis. 2010 May;14[5]:616-21. PMID: 20392356.

7. Hazra A, Gogtay N. Biostatistics Series Module 5: Determining Sample Size. Indian J Dermatol. 2016 Sep-Oct;61[5]:496-504. DOI: 10.4103/0019-5154.190119.

8. Behzadifar M, Heydarvand S, Behzadifar M, Bragazzi NL. Prevalence of Hepatitis C Virus in Tuberculosis Patients: A Systematic Review and Meta-Analysis. Ethiop J Health Sci. 2019 Jan;29[1]:945-956. DOI: 10.4314/ejhs.v29i1.17.

9. Wang JY, Liu CH, Hu FC, Chang HC, Liu JL, Chen JM, et al. Risk factors of hepatitis during anti-tuberculous treatment and implications of hepatitis virus load. J Infect. 2011 Jun;62[6]:448-55. DOI: 10.1016/j.jinf.2011.04.005.

10. Friedland G. Infectious disease comorbidities adversely affecting substance users with HIV: hepatitis $\mathrm{C}$ and tuberculosis. J Acquir Immune Defic Syndr. 2010 Dec;55 Suppl 1[0 1]:S37-42. DOI: 10.1097/QAI.0b013e3181f9c0b6.

11. Reis NR, Lopes CL, Teles SA, Matos MA, Carneiro MA, Marinho TA, et al. Hepatitis $C$ virus infection in patients with tuberculosis in Central Brazil. Int J Tuberc Lung Dis. 2011 Oct;15[10]:1397-402. DOI: 10.5588/ijtld.10.0636.

12. Sirinak C, Kittikraisak W, Pinjeesekikul D, Charusuntonsri $P$, Luanloed P, Srisuwanvilai LO, et al. Viral hepatitis and HIVassociated tuberculosis: risk factors and TB treatment outcomes in Thailand. BMC Public Health. 2008 Jul 18;8:245. DOI: 10.1186/1471-2458-8-245.

13. Richards DC, Mikiashvili T, Parris JJ, Kourbatova EV, Wilson JC, Shubladze N, et al. High prevalence of hepatitis $C$ virus but not HIV co-infection among patients with tuberculosis in Georgia. Int J Tuberc Lung Dis. 2006 Apr;10[4]:396-401. PMID: 16602403.

14. Kuniholm MH, Mark J, Aladashvili M, Shubladze N, Khechinashvili G, Tsertsvadze T, del Rio C, Nelson KE. Risk factors and algorithms to identify hepatitis $C$, hepatitis $B$, and HIV among Georgian tuberculosis patients. Int J Infect Dis. 2008 Jan;12[1]:51-6. DOI: 10.1016/j.jijid.2007.04.015.
15. Khalili H, Dashti-Khavidaki S, Rasoolinejad M, Rezaie L, Etminani M. Anti-tuberculosis drugs related hepatotoxicity; incidence, risk factors, pattern of changes in liver enzymes and outcome. J Pharm Sci. 2009;17 [3]:163-167.

16. Merza MA, Haji SM, Alsharafani AM, Muhammed SU. Low prevalence of hepatitis $B$ and $C$ among tuberculosis patients in Duhok Province, Kurdistan: Are $\mathrm{HBsAg}$ and anti-HCV prerequisite screening parameters in tuberculosis control program? Int J Mycobacteriol. 2016 Sep;5[3]:313-317. DOI: 10.1016/j.jmyco.2016.06.019.

17. Behzadifar M, Heydarvand S, Behzadifar M, Bragazzi NL. Prevalence of Hepatitis C Virus in Tuberculosis Patients: A Systematic Review and Meta-Analysis. Ethiop J Health Sci. 2019 Jan;29[1]:945-956. DOI: 10.4314/ejhs.v29i1.17.

18. Javed I, Javed MT, Mahmood Z, Riaz M, Iqbal R, Rasul A. Hematological profiling of tuberculosis-infected and co-morbid patients: a study carried out in central Punjab, Pakistan. Eur J Inflamm. 2018 Dec;16. DOI: 10.1177/2058739218818684.

19. Çelikbilek M, Selçuk H, Yilmaz U. The effect of hepatotropic virus [HBV-HCV] infections on tuberculin skin test in patients with cirrhosis. Turk J Gastroenterol. 2012 Jun;23[3]:234-8. DOI: 10.4318/tjg.2012.0341.

20. Elhabashy M, Alasdoudy AA, Alhelbawy M, Meleigy M. Latent tuberculosis in patients with hepatitis $C$ infection before receiving antiretroviral drugs. The Egypt $\mathrm{J}$ Chest Dis Tuberc. 2018 Jul 1;67[3]:306-311. DOI: 10.4103/ejcdt.ejcdt_11_18.

21. Conradie F, Diacon AH, Ngubane N, Howell P, Everitt D, Crook AM, et al.; Nix-TB Trial Team. Treatment of Highly DrugResistant Pulmonary Tuberculosis. N Engl J Med. 2020 Mar 5;382[10]:893-902. DOI: 10.1056/NEJMoa1901814.

22. Seung KJ, Franke MF, Hewison C, Huerga H, Khan U, Mitnick CD; end TB Study Group. High prevalence of hepatitis C infection among multidrug-resistant tuberculosis patients. J Hepatol. 2020 May;72[5]:1028-1029. DOI: 10.1016/j.jhep. 2019.10.018.

23. Darwish A, Elhabashy MM., Ali G, Elshorbagy H. Effect of hepatitis $C$ virus infection on patients with pulmonary tuberculosis. The Egypt J Chest Dis Tuberc. 2019; 68[2]:150154. DOI: 10.4103/ejcdt.ejcdt_127_18. 


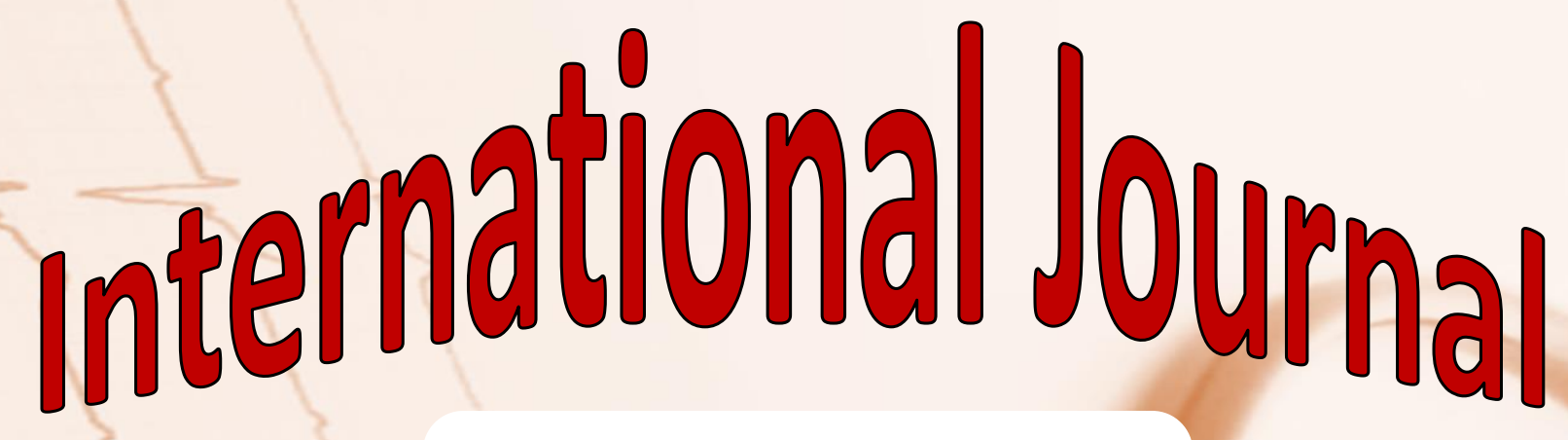

https://ijma.journals.ekb.eg/ Print ISSN: 2636-4174 Online ISSN: 2682-3780

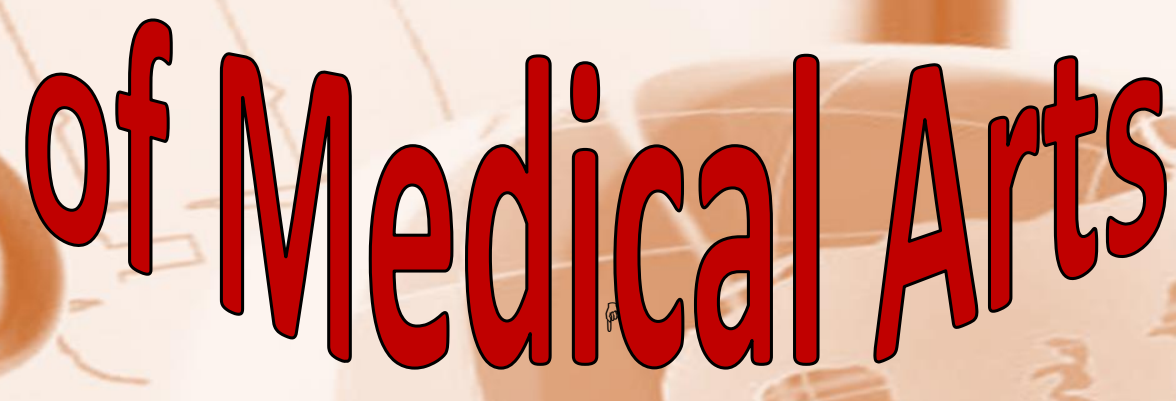

